Article

\title{
Reuse of Agriculture Drainage Water in a Mixed Land-Use Watershed
}

\author{
Agbortoko Ashu(D) and Sang-Il Lee* \\ Department of Civil and Environmental Engineering, Dongguk University, Seoul 04620, Korea; \\ bateashu@gmail.com \\ * Correspondence: islee@dongguk.edu; Tel.: +82-2-2260-3353
}

Received: 6 November 2018; Accepted: 18 December 2018; Published: 22 December 2018

\begin{abstract}
Water demand in Korea has triggered the need for fresh water to be used for agriculture. Agricultural drainage water (ADW) is a way of coping with the growing demand for fresh water for agriculture. In this study, a water quality model (WQM), and an algorithm were used in order to determine the water quality and optimize the water reuse quantity in the Osan stream drain, South Korea. The water quality associated with the drain was stimulated using the QUAL2Kw model and the uncertainty analysis and sensitivity analysis with the use of Monte Carlos Simulation was performed to determine the performance of the WQM. Jaya algorithm technology was used as an optimization tool to find optimal ADW reuse quantities at particular withdrawal points. For calibration and validation, the model was applied twice for both summer and winter seasons. The results show that the reuse quantities represent $77.2 \%$ and $49.8 \%$ of the available ADW in the study area for summer and winter, respectively, representing $49.1 \%$ and $54.5 \%$ of seasonal canal delivery. The utilization of the simulation-optimization model is usually well suited for decision support leading to near-optimum reuse assortment of ADW for irrigation.
\end{abstract}

Keywords: QUAL2Kw; agricultural drainage water (ADW); simulation; optimization; Jaya algorithm; reuse; water quality

\section{Introduction}

In the last century, water use increased worldwide at more than twice the population rate. In arid regions, water use increasingly reaches the limit where water services can be delivered sustainably. About one-fifth of the total population, live in shortage regions. Another 1.6 billion people, or about a quarter of the total population, face financial water shortages [1]. About 20 hectares of agricultural land is irrigated by wastewater, and about $10 \%$ of the world's population consumes food products from farmland [2,3].

South Korea faces many water-related challenges, including an increasing population and related industrial and agricultural activities that will raise the demand for water to levels reaching the limits of the accessible supply. In 2007, an aggregate volume of 15.9 billion $\mathrm{m}^{3}$ water was utilized with regard to agriculture in Korea, which involved around $48 \%$ of the aggregate yearly water use in Korea $[4,5]$. In line with the Ministry of Environment [6], the total wastewater treatment limit in Korea is usually 6.6 billion $\mathrm{m}^{3}$ for each year, which often comes to $20 \%$ associated with the aggregate yearly water use. An ongoing nationwide overview on the future water request and source of Korea announced an anticipated deficiency of more than 4.4 billion $\mathrm{m}^{3}$ of water by $2020[4,7]$.

The Korean Government has been implementing wastewater reclamation projects for agricultural land, mainly for paddy fields, since 2005 and the reused amount in 2011 reached 45 million $\mathrm{m}^{3}$. Most wastewater reuse in agriculture is indirect, which means that the wastewater is disposed of into streams and the diluted wastewater is used for irrigation [8]. Therefore, farms near Wastewater Treatment 
Plants (WWTPs), which are significantly affected by the effluent quality of a WWTP, particularly in the dry season [9], are likely to be expanded. In both direct and indirect wastewater reuse, disposal levels of WWTPs affect irrigation water quality. In the case of reuse of indirect wastewater, the hydrological conditions under which the treated wastewater is diluted also affect irrigation water in addition to the level of disposal. Therefore, before any analysis of the effects of indirect wastewater reuse, it is important to address how irrigation water is affected by WWTP effluent on irrigation water. Optimizing the water quality and quantity of reused drainage water is, therefore, the primary issue of any strategic plan for the effective management of water in South Korea.

Through the years, SWQMs have increasingly already been recognized to support decisionmaking and water quality management. Recently several SWQMs were developed to evaluate and predict the quality of water in streams. QUAL2Kw is a model with different parameters for flexible and applicable water quantity and quality simulation in different settings [10-13]. The complex relationship between waste loads and the resulting water quality is best described in the QUAL2Kw model in the receiving water bodies [14,15].

Regardless of the wealth of studies on wastewater irrigation, few studies have been conducted on the influence of WWTP effluents on irrigation water in situations where indirect wastewater reuse accounts for the majority of wastewater reuse. Other studies have been done with QUAL2Kw and Genetic algorithm, but none have assessed QUAL2Kw and Jaya algorithm which is a new algorithm.

Water quality for irrigation will have declined, due to mixed land use along the Osan stream. This study aims to simulate ADW reuse by integrating a WQM (QULA2Kw) in the mixed land use watershed. The research used the QUAL2Kw model to study the water quality of the Osan drain and its environs. Uncertainty and sensitivity analyses have been carried out to ensure the reliability of the ADW quality and quantity simulation using QUAL2Kw. The Jaya Algorithm technique was then applied as an optimization tool to determine the optimal reuse quantities of ADW.

\section{Study Area}

The QUAL2Kw model was applied to the Osan River watershed situated in central Korea with latitude and longitude which range from N $37^{\circ} 05^{\prime} 56^{\prime \prime}$ to $N 37^{\circ} 14^{\prime} 05^{\prime \prime}$ and from E $127^{\circ} 01^{\prime} 29^{\prime \prime}$ to E $127^{\circ} 09^{\prime} 38^{\prime \prime}$, respectively (Figure 1). The Osan River watershed is suitable for the study watershed since it includes the Osan WWTP, which has a treatment capacity of $140,000 \mathrm{~m}^{3} \mathrm{~d}^{-1}$, downstream from the main water body. A pumping station that irrigates diluted effluent discharge to paddy fields is situated approximately $1 \mathrm{~km}$ downstream from the WWTP. In this study, the main use irrigation water source is drainage water reuse, hence Tap-dong WWTP water is mixed with fresh Osan stream irrigation water. The canals are not labeled and the flow rates are not measured. The mixed water is used by the farmers in the Osan watershed for farming. Land use data for 2009 of the watershed is available at the Ministry of Environment (MOE). It is characterized, as follows- $32.3 \%$ forest, $26.1 \%$ built-up, $18.3 \%$ paddy, $8.1 \%$ bare soil, $6.2 \%$ upland, and $3.5 \%$ water. The average effluent water quality from the WWTPs at the time of 2011 was presented as $10.1 \mathrm{mg} \mathrm{L}^{-1}$ for total nitrogen (T-N), $0.8 \mathrm{mg}$ $\mathrm{L}^{-1}$ for total phosphorus (T-P), and $155 \mathrm{MPN} 100 \mathrm{~mL}^{-1}$ for total coliform. Additionally, it satisfied the effluent standard for WWTPs in Korea. On the other hand, it was reported that some agricultural land remained irrigated with untreated wastewater [14] and limited research has been carried out into various domestic examples of wastewater irrigation. The study watershed has a temperate monsoon climate. The average temperature is approximately $12{ }^{\circ} \mathrm{C}$, and the yearly average precipitation is approximately $1312 \mathrm{~mm}$. Two-thirds of annual rainfall in the summer season lasts from June to August. The study watershed furthermore has an area of $98.3 \mathrm{~km}^{2}$, drainage density of $0.52 \mathrm{~km}^{-2}$, main river length of $16.49 \mathrm{~km}$, and drainage slope of $10.21 \%$. At the Tap-Dong streamflow gauge station, which is managed by the Ministry of Land, Infrastructure, and Transport (MOLIT), daily streamflow from the watershed was measured in real-time. The National Institute of Environmental Research (NIER) monitored the water quality, including TDS, DO, BOD, $\mathrm{NH}_{4}-\mathrm{N}, \mathrm{NO}_{3}-\mathrm{N}, \mathrm{NO}_{2}-\mathrm{N}$, and COD at the watershed outlet (Osan stream 1, 1.2, 1.3, 2, 2.1 and 3 stations) on a monthly basis. 


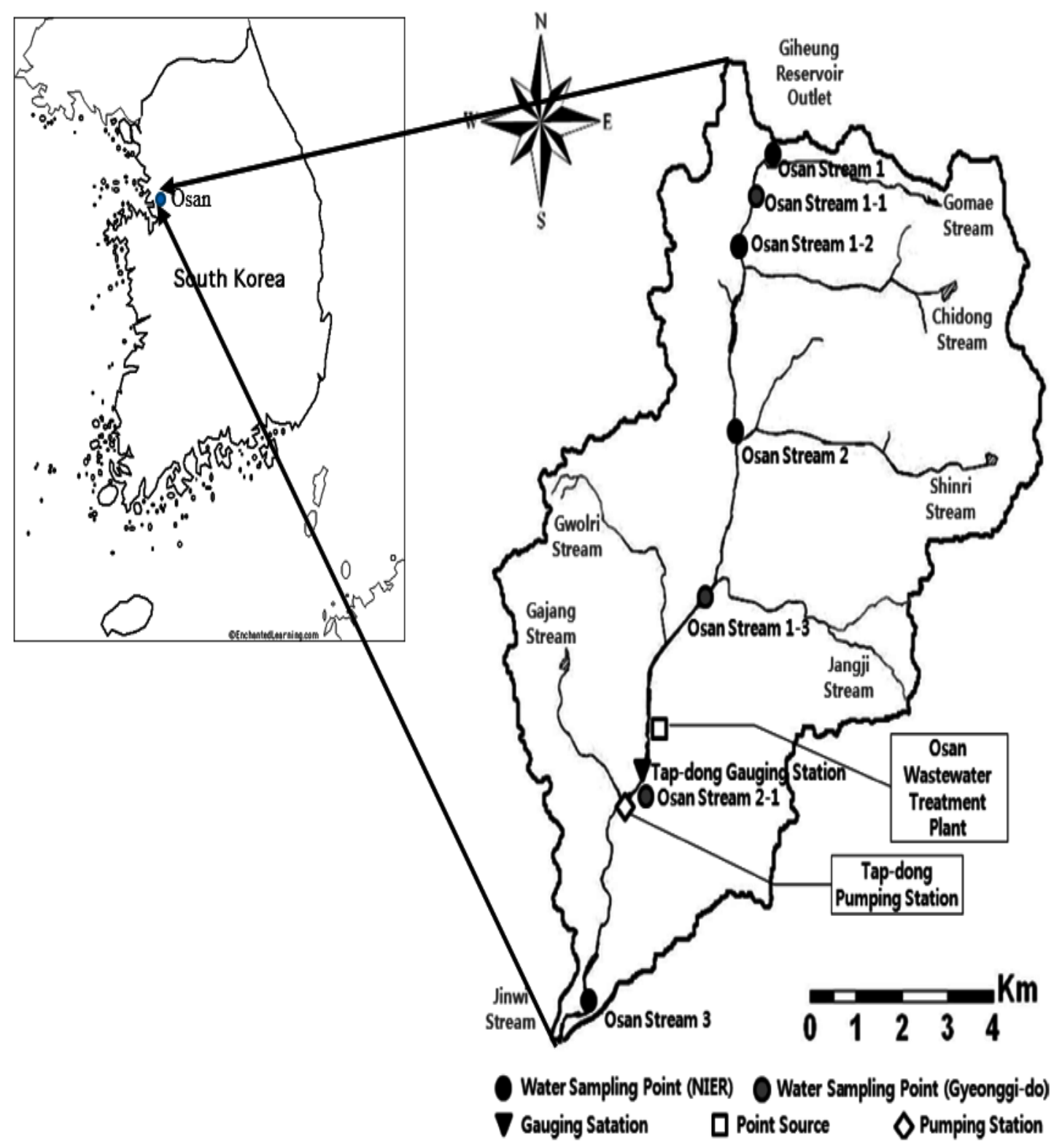

Figure 1. Location of the study area.

In this study, the average monthly records of water quality for January 2015 and July 2016 were collected for 6 locations from the mainstream. The average monthly records of dissolved oxygen (DO), temperature, $\mathrm{pH}$, biological oxygen demand (BOD), total dissolved solutes (TDS), total nitrogen (TN), chemical oxygen demand (COD), total phosphorous (TP) and total suspended solids (TSS) and so on were measured according to [16]. Water quality variables for the 6 monitoring locations, as shown in Table 1 below. In South Korea, the Ministry of Environment [17] proclaimed standards for water quality for treated wastewater are based their specific purpose of use. 
Table 1. Water quality average at the monitoring points of Osan stream drain from January 2015 to July 2016.

\begin{tabular}{|c|c|c|c|c|c|c|c|c|c|c|c|}
\hline Monitoring Point & Distance (km) & $\mathrm{pH}$ & DO (mg/L) & BOD (mg/L) & COD (mg/L) & TSS (mg/L) & $\mathrm{TN}(\mathrm{mg} / \mathrm{L})$ & $\mathrm{TP}(\mathrm{mg} / \mathrm{L})$ & TOC (mg/L) & $\mathrm{NH}_{4}-\mathrm{N}(\mathrm{mg} / \mathrm{L})$ & $\mathrm{NO}_{3}-\mathrm{N}(\mathrm{mg} / \mathrm{L})$ \\
\hline Osan stream 1 & 15.59 & 7.9 & 10.2 & 2.4 & 7.6 & 5.6 & 4.131 & 0.062 & 6.9 & 0.35 & 2.452 \\
\hline Osan stream 1-2 & 14.39 & 7.7 & 10 & 2.8 & 7.4 & 22 & 4.72 & 0.071 & 6.8 & 0.227 & 2.578 \\
\hline Osan stream 1-3 & 10.83 & 8 & 11.7 & 1.5 & 5.1 & 9.7 & 6.145 & 0.353 & 3.5 & 0.221 & 4.411 \\
\hline Osan stream 2 & 8.73 & 7.8 & 10.4 & 1.6 & 6.3 & 17 & 4.212 & 0.117 & 5.7 & 0.134 & 2.691 \\
\hline Osan stream 2-1 & 5.15 & 7.8 & 10.8 & 4.7 & 7.7 & 7.5 & 9.108 & 0.64 & 5.6 & 3.038 & 5.27 \\
\hline Osan stream 3 & 0.49 & 7.6 & 9.3 & 6.4 & 8.8 & 24.1 & 6.43 & 0.316 & 8 & 1.15 & 2.869 \\
\hline
\end{tabular}




\section{Methods}

In this study, the simulation optimization model was developed to achieve near- optimal mixing ratios between ADW and fresh (canal) water at the reused sites. The Osan stream drain was simulated by QUAL2Kw. The SWQM model yields the water quality parameters which include biological oxygen demand (BOD), dissolved oxygen (DO), and total suspended solids (TSS) along the drainage network. Uncertainty and sensitivity analyses, based on MCS were used to evaluate the accuracy of the model and Jaya Algorithm to optimize the total reuse of the proposed reuse sites. In the simulation optimization framework, the SWQM and the optimization methods are combined.

\subsection{Water Quality Modeling}

The SWQM is a one-dimensional and steady stream flow/water quality model. The SWQM can simulate up to 4 user-specified water quality components. Simulated here were two non-conservative constituents (BOD and DO concentrations) and two conservative constituents (TSS and TN concentrations). QUAL2Kw is a stationary and one-dimensional stream modeling designed to represent a modernized version of the U.S. EPA standard river water quality model: QUAL2E [18] to QUAL2Kw. The framework also includes a number of new features that can be applied to shallow and upland streams, as well as more current science. QUAL2Kw simulates the transport and fate of conventional pollutants. The model represents the river as a one-dimensional channel with a steady, non-uniform flow and simulates both point and non-point pollutants.

The QUAL2Kw model simulates the transport and various constituents, such as temperature, wind speed, dew point, temperature, dissolved oxygen, phytoplankton, carbonaceous biochemical oxygen demand, phosphorus, and nitrogen etc. It also simulates several other constituents not typically included in the generally available software, and it is free software. The model simulates pathogenic bacteria, $\mathrm{pH}$, alkalinity, inorganic suspended solids, and ground algae in particular. The inclusion of bottom algae is essential for the simulation of shallow streams so that these algae have a new feature of the nitrogen and phosphorus nutrient variable stoichiometry.

The QUAL2Kw model has other functions that distinguish it from all other models. In other words, oxygen and nutrient flows are calculated on the basis of particulate organic matter, sediment reactions and soluble forms concentrations in overlying waters. The hyporheic zone is modeled, therefore it is the area under the stream bed where water flows through spaces between rocks and cobbles. It is also a necessary feature to simulate shallow streams.

QUAL2Kw has been installed in Microsoft Excel. It is programmed in Visual Basic for Applications (VBA). Input data, model execution, and output viewing was a graphical user interface that was performed in excel. In a model run, a compiled FORTRAN 95 program run by the Excel VBA program performs numerical integration. Constituent concentration $\left(c_{i}\right)$ of mass balance in the water column of a reach is written as

$$
\frac{d c_{i}}{d_{t}}=\frac{Q_{i-1}}{V_{i}} c_{i-1}-\frac{Q_{i}}{V_{i}} c_{i}-\frac{Q_{a b, i}}{V_{i}} c_{i}+\frac{E_{i-1}^{\prime}}{V_{i}}\left(c_{i-1}-c_{i}\right)+\frac{E^{\prime}}{V_{i}}\left(c_{i+1}-c_{i}\right)+\frac{W_{i}}{V_{i}}+S_{i},
$$

where $C_{i}$ is the concentration component of water quality, $Q_{i}$ is flow, $V_{i}$ is volume, $E_{i}$ is dispersion coefficient and $W_{i}$ is the outer load component of reach $i . S_{i}$ is the sinks and sources of the component, which are due to a wide number of transformation mechanisms and reactions within reach $i$. $Q_{o u t}, i$ is the flow abstraction from reach $i$.

The source/sink term $\left(S_{i}\right.$ in Equation (1)) requires a large number of parameters for each state variable (e.g., maximum growth rate of bottom algae) to be specific. The user may select which parameters are held at constant values and which are to be optimized by Jaya Algorithm. The QUAL2Kw Documentation and User's Manual describes a comprehensive discussion of the model theory [19] and provides a detailed description of the model [20].

The Osan Stream drain was divided into 5 reaches with different lengths and subdivided into a total of 47 elements of $0.350 \mathrm{~km}$ length (Figure 2). The main criteria for this division were the similarity 
of hydraulic characteristics, including slope and width, in the reach of a canal. Hydraulic characteristics were determined by measuring geometries and water velocities at each sampling location. Manning's equation was used to determine water velocity and the depth of the stream. For all reaches, a Manning roughness coefficient of 0.04 was used [21]. The input parameters for water quality included in the

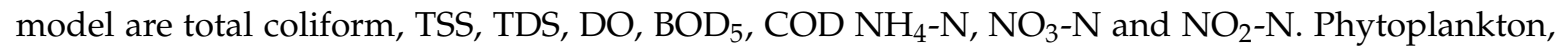
detritus, and pathogens were not measured and were left empty. Algae and bottom oxygen demand were assumed to be $40 \%$ and $100 \%$, respectively. The thickness of the sediment/hyporheic zone was assumed to be $10 \mathrm{~cm}$ and the calculation time step was set at $11.25 \mathrm{~min}$ to prevent model instability. Five days was the number of days of simulation period while Euler's method was done by integration.

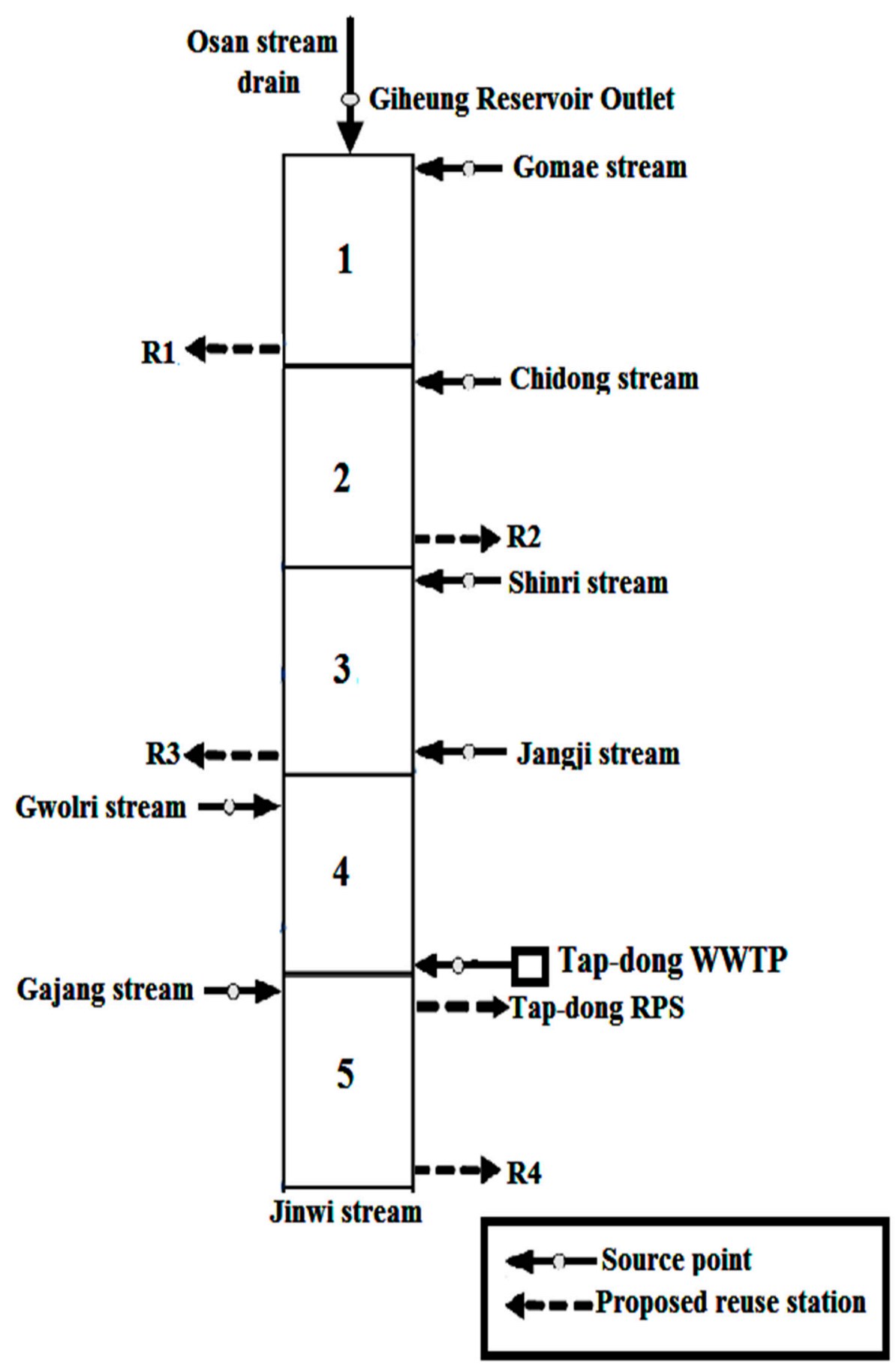

Figure 2. Discretization of Osan Stream drain. 
The QAUL2Kw model was designed for a population size of 100 with 100 generations of evolution [22]. The calibrated parameters values will be the default values for now or same as presented in [23]. For calibration, parameters for the Osan drain QUAL2Kw model using data sets from January 2015 to July 2015. The calibrated model was used for validation with a completely different data set from January 2016 and July 2016 (Water Information system) to aid to the smooth running of the model and to predict the quality and quantity of water under several conditions.

\subsubsection{Uncertainty Analysis}

An uncertainty analysis was executed to assess the uncertainties related to input variable values (BOD, DO, TSS and TN) through QUAL2Kw in order to obtain the statistical measurements of the distributions of the resulting outputs. Random outputs of the QUAL2Kw model within the Osan drain resulting in the magnification of errors in the outputs of the model. It is important to understand the uncertainty in the ability of the QUAL2Kw model hence to predict the drain's behavior and in managing reuse activities to validate the simulated drain. MCS was used to perform Uncertainty analysis in QUAL2Kw model. Monte Carlos Simulation (MCS) is a technique that handles non-normal distributions, complex algorithms, and correlations between input factors for the model in question. This procedure randomly samples input variables from probability distributions without or with correlation, hence our model gives different outputs for each selected variable $[13,24,25]$. The various outputs have been analyzed statistically to assess the uncertainty of predicting the model $[13,26,27]$. The MCS will be perform using YASAIw add-in, is an open source and freely available framework for MCS in Excel [19].

YASAIw is an amendment to the original YASAI add-in developed at Rutgers University [28]. The basic YASAI functionality and theory is detailed [28,29]. YASAI provides Excel functions that return random numbers with specified distributions. They will generally return different, randomly chosen values every time you recalculate a spreadsheet [29]. YASAI is implemented as a single file in the Visual Basic for Applications (VBA) language. Any user on any computer equipped with a reasonably recent version of Excel should be able to use it, provided they are allowed to run Excel macros [30]. YASAI provides only six distributions with no graphics and the graphics can easily be added with great difficulty. In this study, an uncertainty analysis was performed by using the QUAL2Kw model with YASAIw tool to evaluate the input variables in the Osan drain to obtain uncertainty outputs that confirms the QUAL2Kw water quality model. For each output, the model can produce histograms, frequencies, error bars, and probability density functions.

\subsubsection{Sensitivity Analysis}

Sensitivity analysis examines the importance of imprecision in model inputs in modeling or decision-making. In this study, outputs from Monte Carlos Simulation (MCS) produces sensitivity analysis which estimates the correlation among the predicted variables and the chosen input variable hence the contribution to the variance of the predicted variable from the chosen variables in the MCS. Four water quality outputs (BOD, DO, TN and TSS) at one major location (Osan Stream 2-1, $5.15 \mathrm{~km}$ ) was chosen for and sensitivity analyses, because of the presence of a Wastewater treatment plant (WWTP) for both summer and winter respectively. A total of 1000 MCSs were performed to generate 1000 outputs for the four water quality variables. The Monte Carlos Simulation is implemented by simulating the QUAL2Kw model to identify parameters that have the greatest impact on water quality outputs. A total of 66 input variables were chosen, which include BOD, DO, TN and TSS from headwater and QUAL2Kw model calibrated rate constants. In this study, sensitivity analysis produces the contribution to the variance and Spearman's correlation coefficients from each output. Spearman's rank correlation is a nonparametric measure of the correlation that uses the rank of observations in its calculation, rather than the original numeric values. It measures the monotonic relationship between two variables. 
Table 2 presents the mean water quality for summer and winter 2016 at proposed reused stations. Table 3 presents the kinetics parameters adapted from the literature and used in the model calibration process $[18,22]$.

Table 2. Mean water quality for summer and winter 2016 at proposed reused stations.

\begin{tabular}{|c|c|c|c|c|c|c|c|c|c|}
\hline \multirow{3}{*}{ Proposed Reused Station } & \multirow{2}{*}{ Location } & \multicolumn{4}{|c|}{ Summer 2016} & \multicolumn{2}{|c|}{ Winter 2016} & \multirow[b]{2}{*}{ TSS } & \multirow[b]{2}{*}{ TN } \\
\hline & & BOD & DO & TSS & TN & BOD & DO & & \\
\hline & $(\mathrm{km})$ & $(\mathrm{mg} / \mathrm{L})$ & $(\mathrm{mg} / \mathrm{L})$ & $(\mathrm{mg} / \mathrm{L})$ & $(\mathrm{mg} / \mathrm{L})$ & $(\mathrm{mg} / \mathrm{L})$ & $(\mathrm{mg} / \mathrm{L})$ & $(\mathrm{mg} / \mathrm{L})$ & $(\mathrm{mg} / \mathrm{L})$ \\
\hline R1 & 14.36 & 3.3 & 7.4 & 39.8 & 3.4 & 2.2 & 12.5 & 4.2 & 6.1 \\
\hline R2 & 10.81 & 2 & 7.3 & 27.5 & 3.3 & 1.2 & 13.4 & 6.5 & 5.1 \\
\hline R3 & 8.60 & 1.2 & 9.4 & 11.3 & 6.1 & 1.8 & 13.9 & 8 & 6.3 \\
\hline Tap-dong & 5.15 & 3.2 & 9.4 & 7.5 & 9.5 & 6.1 & 12.4 & 7.5 & 11.7 \\
\hline $\mathrm{R} 4$ & 0.49 & 5.2 & 6.6 & 38.8 & 3.8 & 7.6 & 11.9 & 9.4 & 9.1 \\
\hline
\end{tabular}

Table 3. System parameters in the Osan Stream.

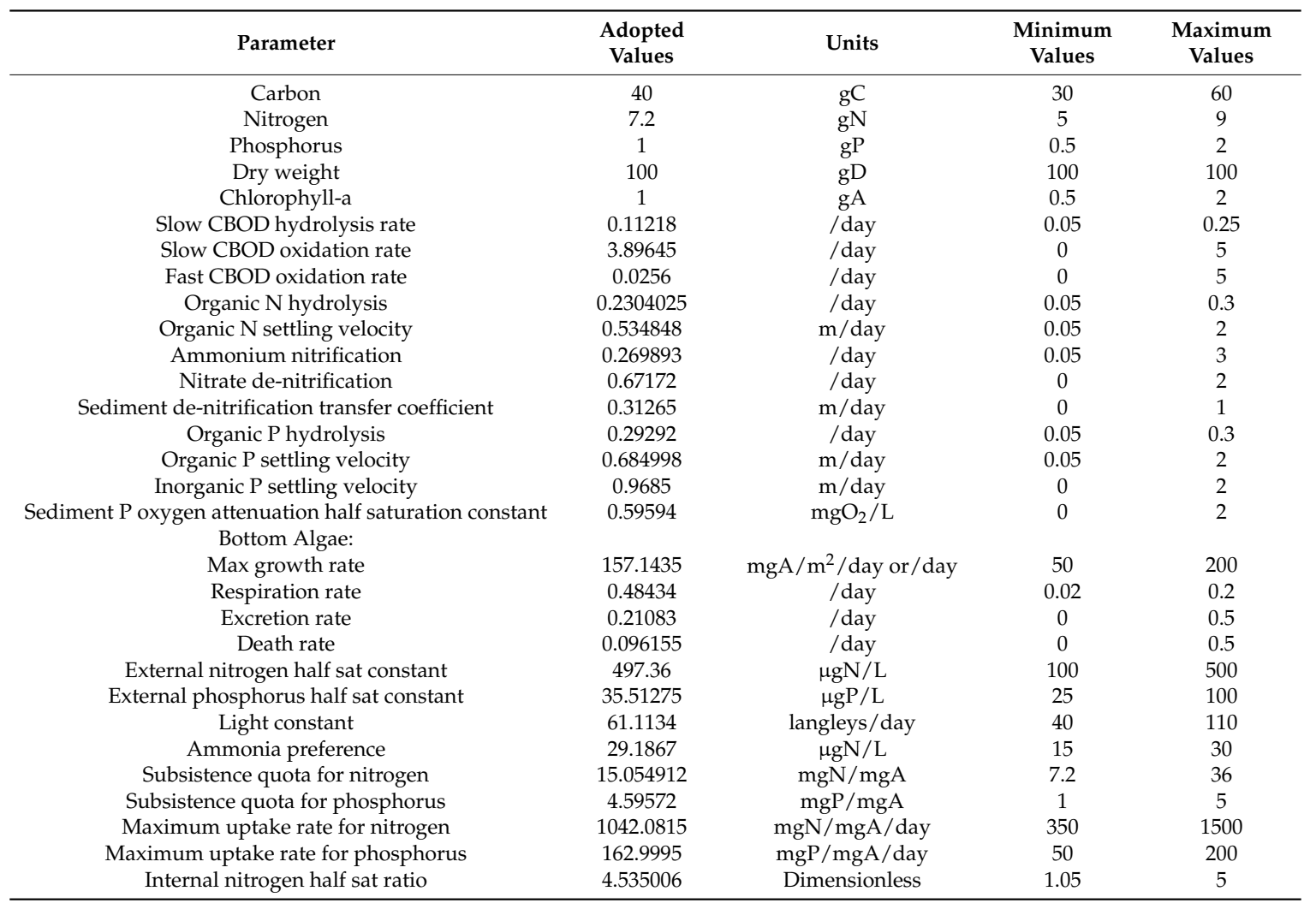

\subsection{Optimization of Drainage Water Reuse}

\subsubsection{Jaya Algorithm}

Jaya algorithm is a new optimization algorithm which has no algorithm-specific controlling parameter for solving constrained and unconstrained optimization problems. In contrast to other population-based heuristic algorithms, only the two ordinary control parameters, population size (m) and generation number $(\mathrm{Gn})$, are included [31]. The basic Jaya algorithm has only one phase of the above concept and is, therefore, a simple technique of optimization. Using binary coding, parameters can represent their values with a high degree of accuracy [31].

To further explain the Jaya Algorithm, let $Q_{j, k, i}^{\prime}$ is the objective function. At any iteration $i$, assume that there are ' $m$ ' number of design variables (i.e., $j=1,2, \ldots, m$ ), ' $n$ ' number of candidate solutions (i.e., population size, $k=1,2, \ldots, n$ ). Let $Q_{j, b e s t, i}$ and $Q_{j, \text { worst }, i}$ be the best and worst candidate solutions 
respectively. If $Q_{j, k, i}$ stands for the value of the variable $j^{\text {th }}$ for the kth candidate during the $i^{\text {th }}$ iteration. The formula is modified and written as the following Equation (2).

$$
Q_{j, k, i}^{\prime}=Q_{j, k, i}+r_{1, j, i}\left(Q_{j, b e s t, i}-\left|Q_{j, k, i}\right|\right)-r_{2, j, i}\left(Q_{j, \text { worst }, i}-\left|Q_{j, k, i}\right|\right),
$$

where, $Q_{j, b e s t, i}$ stands for the $j^{t h}$ variable for the best candidate and $Q_{j, w o r s t, i}$ stands for the $j^{\text {th }}$ variable for the worst candidate. $Q_{j, k, i}^{\prime}$ is the updated value of $Q_{j, k, i}$ and $r_{1, j, i}$ and $r_{2, j, i}$ are the two random numbers in the range [0,1]. This " $r_{1, j, i}\left(Q_{j, b e s t, i}-\left|Q_{j, k, i}\right|\right)$ " shows the tendency to approach to the best solution and the term " $-r_{2, j, i}\left(Q_{j, w o r s t, i}-\left|Q_{j, k, i}\right|\right)^{\prime \prime}$ shows the tendency to avoid the worst solution. $Q^{\prime j, k, i}$ is accepted if it's better than the previous candidate or it's maintained [31].

The Jaya algorithm does need any algorithm-specific parameters, which requires extensive calibration before conducting the actual computational experiments, if not done correctly, leads unavoidable and unwanted convergence. The controlling of the algorithm-specific parameters is not as easy as it looks. Also, controlling the parameters in each iteration is most of the time difficult and time-consuming. This entire process does not belong to the Jaya algorithm. The main reason is the victorious nature of the Jaya algorithm, which makes it more powerful than any other algorithm.

\subsubsection{Jaya Algorithm Application}

The Jaya algorithm is used as an optimization tool to maximize the ADW reuse quantities at the proposed reuse sites unless the standards for the use of mixed water in irrigation have been violated. In the simulation-optimization framework, the Jaya algorithm, and the QUAL2Kw model will be combined to achieve the optimum use of ADW in the Osan drain.

The aim is to maximize the removal of ADW from the drain to the mixing sites on the canal (Figure 3).

$$
\operatorname{Maximum} Q_{t}=\sum_{i=1}^{n} Q_{r, i}
$$

Subject to

$$
\begin{aligned}
B O D_{c} & \leq B O D_{c, \text { max }}, \\
T S S_{c} & \leq T S S_{c, \text { max }}, \\
D O_{c} & \geq D O_{c, \text { min }}
\end{aligned}
$$

where $Q_{t}$ is the total ADW reuse drain discharges. $T S S_{c}=$ TDS concentration $(\mathrm{mg} / \mathrm{L})$ for the irrigation water downstream from the mixing location in a canal c; $T S S_{c ; m a x}=$ maximum permissible concentration of TSS $(\mathrm{mg} / \mathrm{L})$ for irrigation water; $B O D_{c}=$ BOD concentration $(\mathrm{mg} / \mathrm{L})$ for the irrigation water downstream from the mixing location; $B O D_{c ; m a x}=$ maximum permissible $\mathrm{BOD}$ concentration $(\mathrm{mg} / \mathrm{L})$ for irrigation water; $D O c=$ concentration of $\mathrm{DO}(\mathrm{mg} / \mathrm{L})$ for the irrigation water downstream from the mixing location; and $D O_{c ; m i n}=$ minimum permissible concentration of $\mathrm{DO}(\mathrm{mg} / \mathrm{L})$ for irrigation water.

The Osan stream drain is composed of many individual outlets from the stream made by the farmers. To optimize this drain we assumed five proposed reuse locations due to the availability of water quality parameters and due to the unavailability of data on flow and water quality parameters, the flow rate of the stream for the past 8 years was used to extrapolate the flow rate at various locations. The water quality parameters were extrapolated from the water quality data at the monitoring points. 


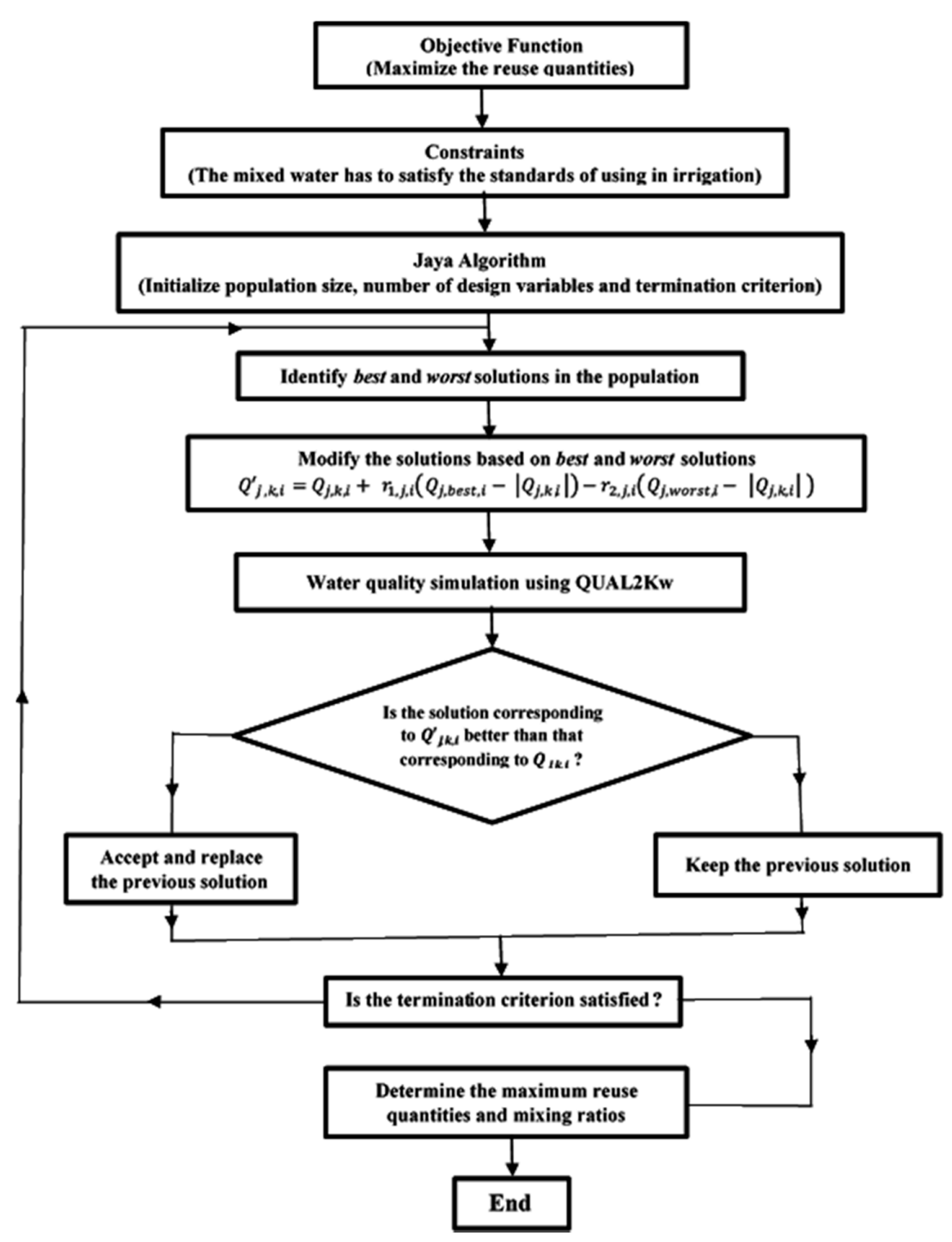

Figure 3. Flowchart of the optimization model.

\section{Results and Discussion}

This optimization model was applied to the 2016 summer and winter Osan for the maximum and minimum reuse of the ADW. Water quality and quantity data were therefore used in the winter (January 2016) and summer (July 2016) to model the drainage water quality and quantity of the Osan drain. QUAL2Kw model calibrated parameters were not changed. Our choice of the month January to represent the winter period was due to the low rainfall index and the great influence of the contribution of the diffuse load for the water quality. Similarly, our choice of the month of July to represent the summer period was due to the higher rainfall indices. In two subsequent Jaya Algorithm experiments, QUAL2Kw models were used for summer and winter. Given that agricultural water consumption accounts for more than $47 \%$ of total water consumption and the trend towards reuse in Korea is generally increasing $[25,32]$, it is important to categorize the culture of reuse of wastewater and to introduce representative cases at the local level for a safe and sustainable environment.

\subsection{Water Quality Simulation}

The simulation model was executed twice by using completely different data sets from summer and winter 2016 to represent seasons with maximum and minimum ADW reuse requirements. In order to simulate this drainage system, it is divided into five reaches on the basis of its hydraulic 
characteristics. The model predictions along the Osan stream drain were plotted and summarized in Figure 4 below.
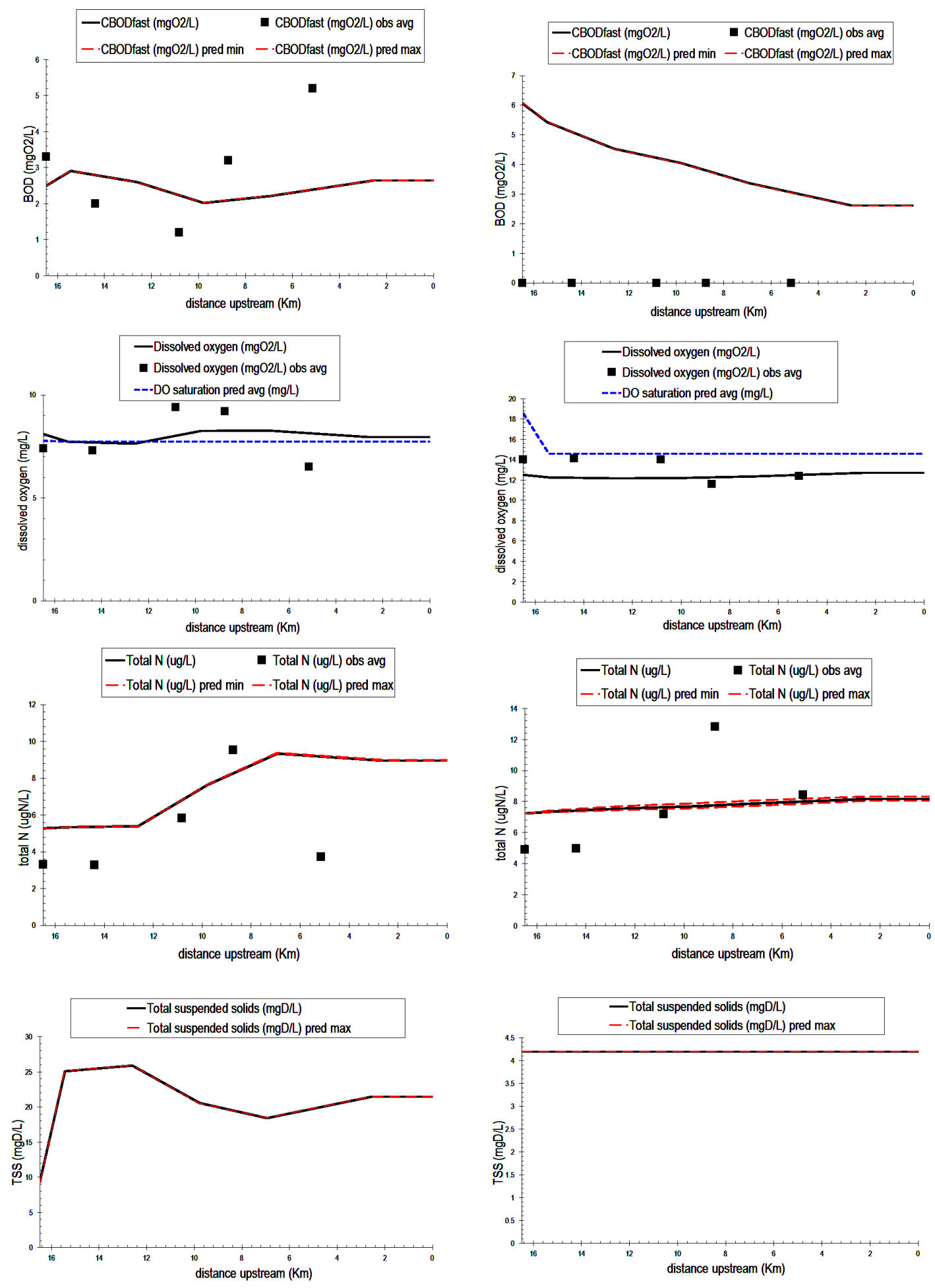

(a) Summer

(b) Winter

Figure 4. Water quality simulation 2016 results for the Osan stream drain.

Water quality properties (TSS, TN, BOD and DO concentrations) and flow rates measured on 25 January 2016 and 24 July 2016 are used to create models for the summer and winter seasons. 
The direct flow of ADW into these drains is simulated by the distributed flow along the Osan stream. For winter and summer simulations, this value was found to be $1.34 \mathrm{~m}^{3} / \mathrm{s}$ and $1.85 \mathrm{~m}^{3} / \mathrm{s}$.

TSS, TN, BOD and DO along the drainage canal ranged from $0.92,1.22,0.75$ and $5.26 \mathrm{mg} / \mathrm{L}$ for winter and 3.30, 9.46, 2.08 and $8.0 \mathrm{mg} / \mathrm{L}$ for summer, respectively, in the calibration (January 2015 to December 2015) to $4.20,7.88,1.12$ and $12.37 \mathrm{mg} / \mathrm{L}$ for winter and $17.88,9.34,0.03$ and $8.28 \mathrm{mg} / \mathrm{L}$ for summer, respectively, in the validation (January 2016 to December 2016).

$\mathrm{DO}$ is always greater than $2 \mathrm{mg} / \mathrm{L}$, so it meets the 4 th grade criterion for streams, and BOD meets the criteria of $8 \mathrm{mg} / \mathrm{L}$. In the case of T-N and T-P, there is no standard for the lower level. Therefore, it is compared with the water quality recommendation standard [5].

Along the drain, BOD ranged from 0.10 to $0.4 \mathrm{mg} / \mathrm{L}$ for summer and from 0.84 to $2.20 \mathrm{mg} / \mathrm{L}$ for winter, as shown in Figure 4. Similarly, the DO ranged from 7.73 to $8.28 \mathrm{mg} / \mathrm{L}$ in summer and from 12.50 to $12.69 \mathrm{mg} / \mathrm{L}$ winter, for reusing drainage water in irrigation in South Korea [15] hence wastewater from the Tap-dong WWTP add high organic and inorganic materials resulted low DO. The water quality standards for agricultural water are classified into four classes of water quality [33].

Furthermore, the results showed that the TSS and T-N values in many drain segments meet the standards (i.e., below 1000 and $15 \mathrm{mg} / \mathrm{L}$ respectively). The TSS concentration for summer increases sharply after $1 \mathrm{~km}$ and decreases downstream hence the presence of pathogens available in the drain while in winter it's in a steady state from headwater to downstream. T-N concentrations increase along the drain, so the impact of fertilizer application in the agricultural drainage basin areas can be attributed.

\subsubsection{Uncertainty Analysis Outcome}

The results suggested that input data were efficiently simulated in the Osan stream drain. The frequency histograms and error bars from the uncertainty analysis show that the data are clumped around the mean for all the simulated variables at the Osan Stream 2-1, $5.15 \mathrm{~km}$ for winter and summer respectively (Figure 5). At Osan Stream 2-1, the mean for the four variables examined suggests that both summer and winter the BOD, DO, TN and TSS predictions are more reliable, as they have a small standard deviation bar. Corresponding values are 0.026, 8.1, 9.3 and 18.35 for summer, and 3.15, 12.37, 4.2 and 7.89 for winter, respectively. The results showed that MCS simulated mean for BOD, DO, TN and TSS increased downstream hence the presence of the wastewater pumping station is located downstream. The results indicated that the likelihood of variables in water quality, namely BOD, DO, TN, and TSS, deviating from observed values was low. The QUAL2Kw model is used in the study and can be used as an intervention analysis for DO, BOD, TN, and TSS. The model can, therefore, be used effectively to manage water quality.
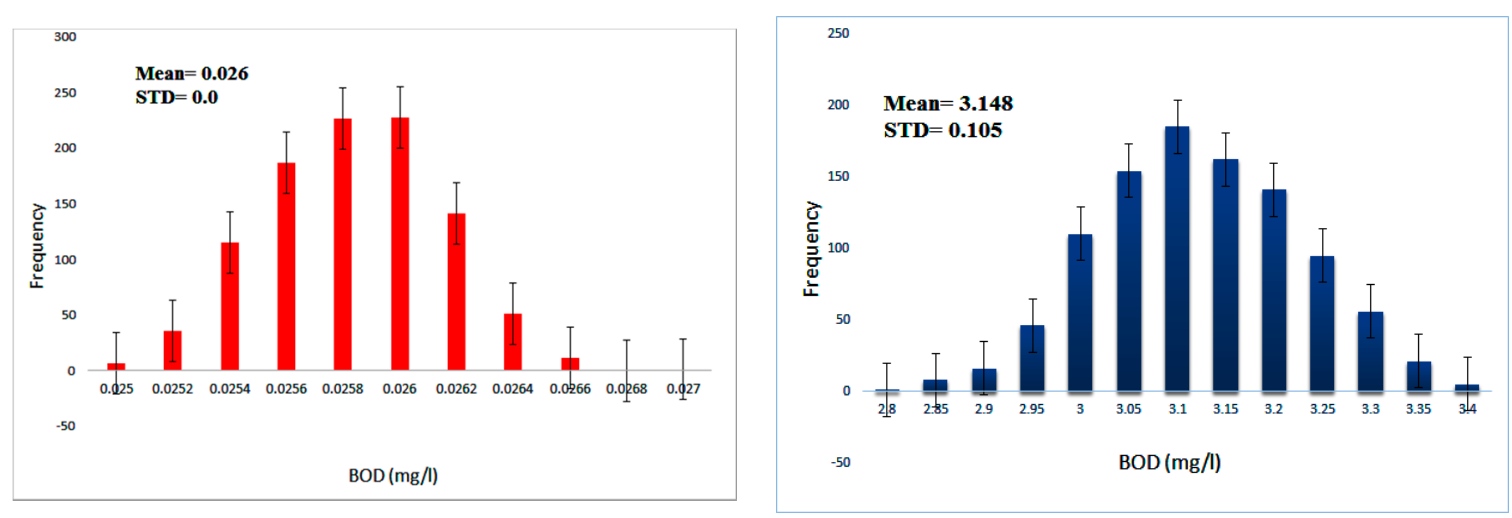

Figure 5. Cont. 

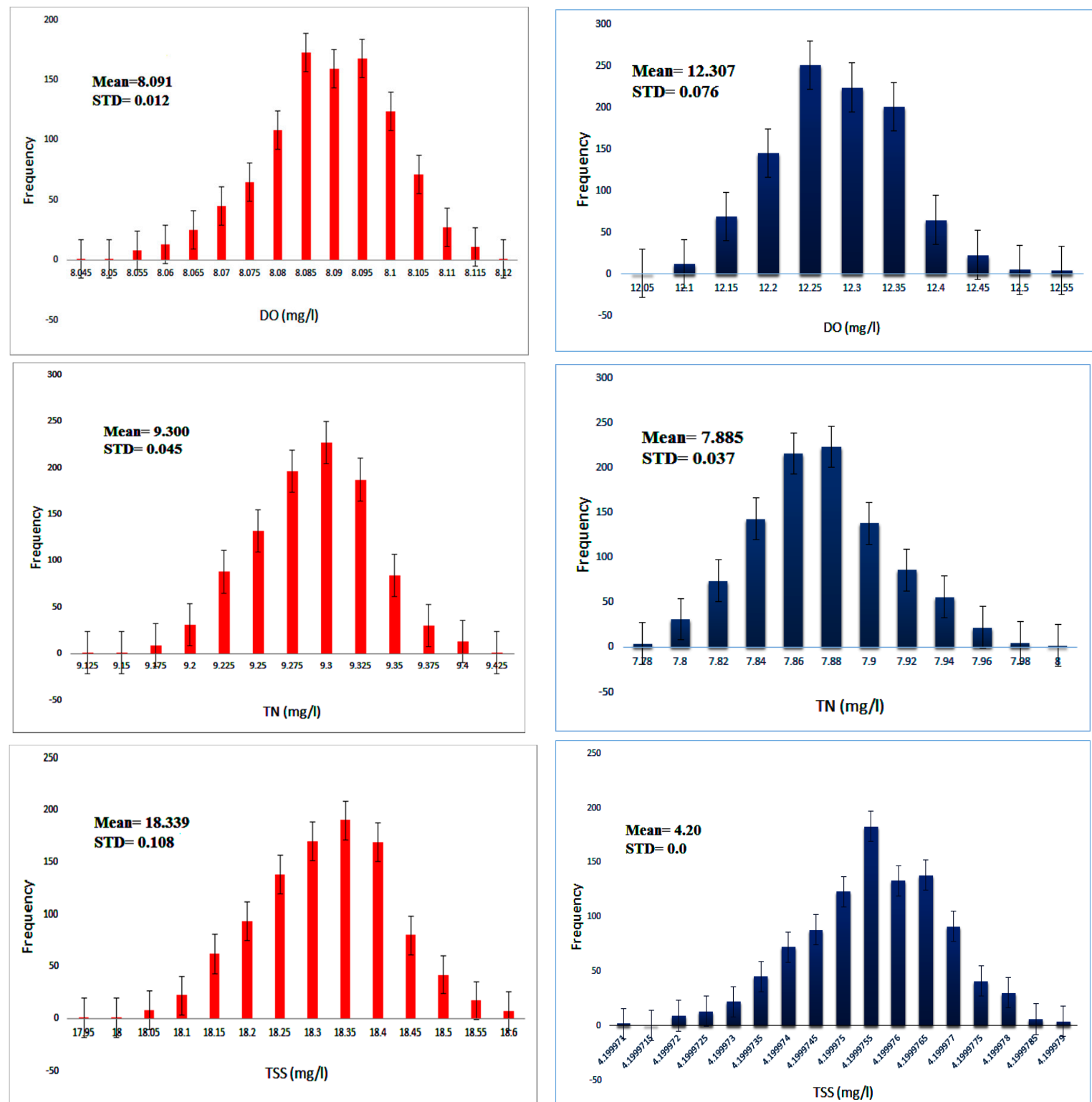

(a) Osan stream 2-1 Summer (Distance $5.15 \mathrm{~km}$ )

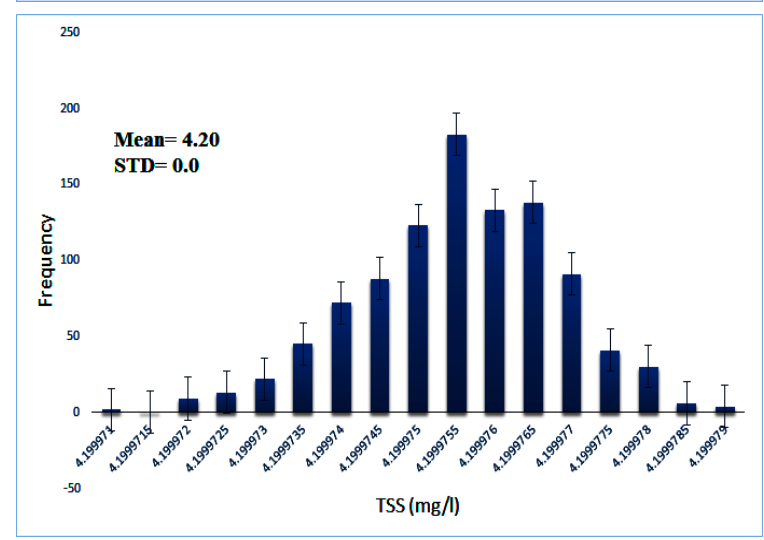

(b) Osan stream 2-1 Winter (Distance $5.15 \mathrm{~km}$ )

Figure 5. Error bars and frequency distribution from uncertainty analysis for BOD, DO, TN and TSS for summer and winter at Osan stream 2-1.

\subsubsection{Sensitivity Analysis Results}

The results of the sensitivity analysis showed that the contribution to variance parameter makes up about $95 \%$ of the BOD, DO, TN and TSS variance at Osan Stream 2-1 both in summer and in winter. Table 4 showed that Spearman's Rho values of $-0.93,-0.85,-0.92$ and 0.97 for winter and -91.1 , $0.80,-0.71$ and -0.75 for summer were the highest input for BOD, DO, TN and TSS outputs at the Osan Stream 2-1 reuse station. Their contribution to variance were $81.6 \%, 71.5 \%, 80.7 \%$, and $88.1 \%$ for winter and $76.6 \%, 64.6 \%, 55.2 \%$ and $48.6 \%$ for summer. This is because of the effect of the drain, which releases its pollution loads into the stream. 
Table 4. Monte Carlo Simulation summary for BOD, DO, TSS, and TN at proposed reuse station.

\begin{tabular}{|c|c|c|c|c|c|c|c|c|}
\hline & \multicolumn{2}{|c|}{ BOD $(\mathrm{mg} / \mathrm{L})$} & \multicolumn{2}{|c|}{ DO (mg/L) } & \multicolumn{2}{|c|}{ TSS (mg/L) } & \multicolumn{2}{|c|}{$\mathrm{TN}(\mathrm{mg} / \mathrm{L})$} \\
\hline & Summer & Winter & Summer & Winter & Summer & Winter & Summer & Winter \\
\hline \multicolumn{9}{|l|}{ Osan Stream 2-1 } \\
\hline Mean & 0.026 & 3.148 & 8.091 & 12.307 & 18.345 & 4.2 & 9.302 & 7.885 \\
\hline Minimum & 0.025 & 2.839 & 8.05 & 12.089 & 17.968 & 4.199 & 9.146 & 7.786 \\
\hline Maximum & 0.027 & 3.424 & 8.121 & 12.592 & 18.649 & 4.2 & 9.427 & 8.017 \\
\hline Range & 0.002 & 0.585 & 0.071 & 0.503 & 0.681 & 0.001 & 0.281 & 0.231 \\
\hline Standard deviation & 0 & 0.105 & 0.012 & 0.076 & 0.105 & 0 & 0.012 & 0.037 \\
\hline Coefficient of variation & 0 & 0.033 & 0.001 & 0.006 & 0.005 & 0 & 0.001 & 0.004 \\
\hline Skewness Coefficient & 0.026 & -0.004 & -0.349 & 0.194 & -0.204 & -0.273 & -0.23 & 0.259 \\
\hline \multicolumn{9}{|l|}{ Osan Stream 3} \\
\hline Mean & 0.038 & 2.375 & 7.74 & 12.66 & 21.344 & 4.2 & 8.922 & 8.179 \\
\hline Minimum & 0.037 & 2.054 & 7.694 & 12.433 & 20.911 & 4.199 & 8.805 & 8.037 \\
\hline Maximum & 0.039 & 2.673 & 7.771 & 12.94 & 21.69 & 4.2 & 9.013 & 8.369 \\
\hline Range & 0.002 & 0.619 & 0.077 & 0.507 & 0.779 & 0.001 & 0.208 & 0.332 \\
\hline Standard deviation & 0 & 0.111 & 0.012 & 0.081 & 0.12 & 0 & 0.033 & 0.053 \\
\hline Coefficient of variation & 0 & 0.047 & 0.002 & 0.006 & 0.005 & 0 & 0.004 & 0.006 \\
\hline Skewness Coefficient & -0.002 & 0.034 & -0.383 & 0.138 & -0.216 & -0.275 & -0.238 & 0.26 \\
\hline
\end{tabular}

\subsection{Optimization of $A D W$ Reuse}

The simulation optimization model using Jaya Algorithm was run independently for summer and winter, representing seasons with maximum and minimum ADW reuse requirements. These two experiments in the Jaya algorithm identified the water quality, the mixing ratio and optimal reuse withdrawals between fresh water and drainage at each mixing point for the experiments. Total reuse quantities were 45.73 and $6.80 \mathrm{~m}^{3} / \mathrm{s}$ for summer and winter, respectively (Table 5). The water quantity in the irrigation canals upstream from the mixing points for summer and winter was 47.35 and $5.75 \mathrm{~m}^{3} / \mathrm{s}$ so that the average mixing ratio between drainage and fresh water was 2.0 in summer and 2.2 in winter. In addition, the criteria for concentrations of BOD, DO, TSS and TN in canal water after mixing at all mixing points met the criteria for irrigation.

The water requirements for irrigation downstream of the reused points were $93.08 \mathrm{~m}^{3} / \mathrm{s}$ for summer and $12.55 \mathrm{~m}^{3} / \mathrm{s}$ for winter (Figure 6). The reused amounts of ADW, therefore, represent $49.1 \%$ and $54.2 \%$ of the summer and winter requirements for fresh water for irrigation. In addition, the total demand for irrigation water for summer and winter was 59.2 and $13.65 \mathrm{~m}^{3} / \mathrm{s}$, with recycled water volumes accounting for $77.2 \%$ and $49.8 \%$ of the available ADW for summer and winter in the study area. Therefore, the amount of ADW released is higher in summer than in winter. The optimization results showed that the Jaya algorithm was used successfully in the management of ADW reuse. Therefore, the amount of ADW released is higher in summer than in winter. The optimization results showed that the Jaya algorithm was used successfully in the management of ADW reuse.

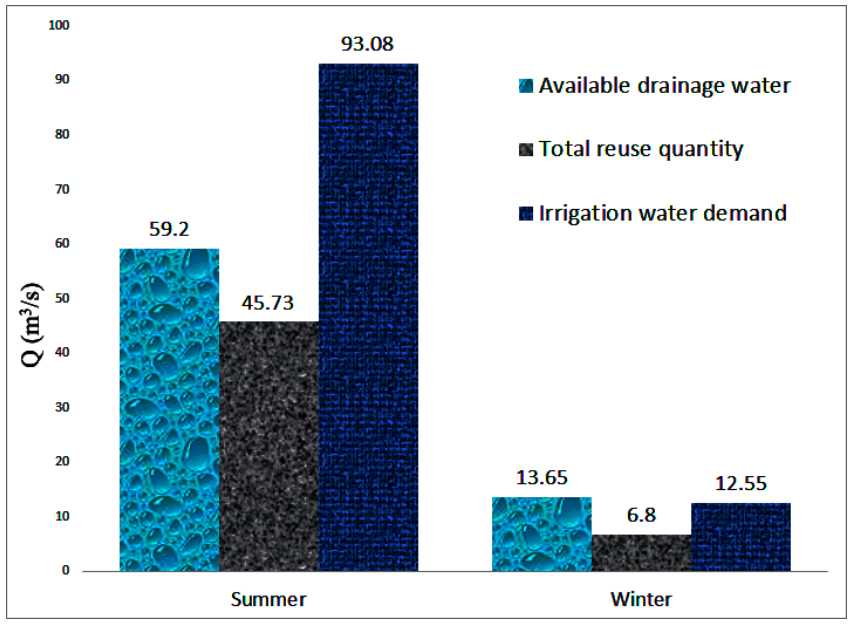

Figure 6. Water demand, availability and reuse in the Osan stream drain. 
Table 5. Jaya Algorithm results at proposed reuse stations during summer and winter 2016.

\begin{tabular}{|c|c|c|c|c|c|c|c|c|c|c|c|c|c|c|c|c|}
\hline \multicolumn{17}{|c|}{ Results for Summer } \\
\hline \multirow{3}{*}{ Proposed Reused Station } & \multicolumn{6}{|c|}{ Drain Water Upstream Mixing Point } & \multicolumn{5}{|c|}{ Canal Water Upstream Mixing Point } & \multicolumn{5}{|c|}{ Canal Water Downstream Mixing Points } \\
\hline & $Q_{d, j}$ & $\mathrm{Q}_{\mathrm{r}, \mathrm{j}}$ & BOD & DO & TSS & TN & $Q_{c, j}$ & BOD & DO & TSS & TN & $\mathbf{Q}_{r, j}^{\prime}$ & BOD & DO & TSS & TN \\
\hline & $\left(\mathrm{m} / \mathrm{s}^{3}\right)$ & $\left(\mathrm{m} / \mathrm{s}^{3}\right)$ & $(\mathrm{mg} / \mathrm{L})$ & $(\mathrm{mg} / \mathrm{L})$ & $(\mathrm{mg} / \mathrm{L})$ & $(\mathrm{mg} / \mathrm{L})$ & $\left(\mathrm{m} / \mathrm{s}^{3}\right)$ & $(\mathrm{mg} / \mathrm{L})$ & $(\mathrm{mg} / \mathrm{L})$ & $(\mathrm{mg} / \mathrm{L})$ & $(\mathrm{mg} / \mathrm{L})$ & $\left(\mathrm{m} / \mathrm{s}^{3}\right)$ & $(\mathrm{mg} / \mathrm{L})$ & $(\mathrm{mg} / \mathrm{L})$ & $(\mathrm{mg} / \mathrm{L})$ & $(\mathrm{mg} / \mathrm{L})$ \\
\hline R1 & 1.85 & 3.90 & 2.91 & 7.73 & 25.09 & 5.34 & 4.01 & 2.51 & 6.91 & 22.23 & 3.65 & 7.91 & 4.12 & 7.58 & 23.59 & 3.89 \\
\hline R2 & 1.85 & 5.92 & 2.59 & 7.63 & 25.92 & 5.38 & 5.98 & 2.15 & 6.74 & 21.56 & 3.25 & 11.9 & 3.95 & 6.99 & 22.99 & 4.10 \\
\hline R3 & 1.85 & 9.95 & 2.03 & 8.25 & 19.99 & 7.64 & 10.56 & 1.87 & 7.15 & 16.58 & 5.98 & 20.51 & 2.56 & 7.89 & 17.23 & 6.65 \\
\hline Tap-dong & 1.85 & 11.97 & 2.22 & 8.28 & 17.88 & 9.34 & 12.21 & 2.02 & 7.09 & 15.67 & 7.59 & 24.18 & 3.22 & 7.58 & 16.48 & 8.49 \\
\hline R4 & 1.85 & 13.99 & 2.64 & 7.94 & 20.90 & 9.85 & 14.59 & 2.05 & 7.01 & 18.12 & 8.11 & 28.58 & 3.01 & 7.25 & 19.56 & 9.03 \\
\hline \multicolumn{17}{|c|}{ Results for winter } \\
\hline & \multicolumn{6}{|c|}{ Drain Water Upstream Mixing Point } & \multicolumn{5}{|c|}{ Canal Water Upstream Mixing Point } & \multicolumn{5}{|c|}{ Canal Water Downstream Mixing Points } \\
\hline \multirow[t]{2}{*}{ Proposed Reused Station } & $Q_{d, j}$ & $Q_{\mathrm{r}, \mathrm{j}}$ & BOD & DO & TSS & $\mathrm{TN}$ & $Q_{c, j}$ & BOD & DO & TSS & TN & $Q_{r, j}^{\prime}$ & BOD & DO & TSS & $\mathrm{TN}$ \\
\hline & $\left(\mathrm{m} / \mathrm{s}^{3}\right)$ & $\left(\mathrm{m} / \mathrm{s}^{3}\right)$ & $(\mathrm{mg} / \mathrm{L})$ & $(\mathrm{mg} / \mathrm{L})$ & $(\mathrm{mg} / \mathrm{L})$ & $(\mathrm{mg} / \mathrm{L})$ & $\left(\mathrm{m} / \mathrm{s}^{3}\right)$ & (mg/L) & $(\mathrm{mg} / \mathrm{L})$ & $(\mathrm{mg} / \mathrm{L})$ & $(\mathrm{mg} / \mathrm{L})$ & $\left(\mathrm{m} / \mathrm{s}^{3}\right)$ & $(\mathrm{mg} / \mathrm{L})$ & $(\mathrm{mg} / \mathrm{L})$ & $(\mathrm{mg} / \mathrm{L})$ & $(\mathrm{mg} / \mathrm{L})$ \\
\hline R1 & 1.34 & 1.36 & 5.43 & 12.26 & 4.20 & 7.35 & 1.15 & 4.95 & 10.95 & 2.96 & 5.94 & 2.51 & 4.99 & 11.23 & 3.02 & 6.25 \\
\hline R2 & 1.34 & 1.36 & 4.52 & 12.18 & 4.20 & 7.56 & 1.15 & 4.01 & 10.84 & 2.86 & 6.35 & 2.51 & 4.23 & 11.06 & 3.11 & 6.98 \\
\hline R3 & 1.34 & 1.36 & 4.04 & 12.20 & 4.20 & 7.68 & 1.15 & 3.26 & 10.21 & 2.52 & 6.38 & 2.51 & 3.56 & 10.89 & 2.88 & 7.41 \\
\hline Tap-dong & 1.34 & 1.36 & 3.36 & 12.37 & 4.20 & 7.88 & 1.15 & 2.42 & 9.97 & 3.52 & 5.84 & 2.51 & 2.68 & 10.13 & 3.95 & 6.68 \\
\hline R4 & 1.34 & 1.36 & 2.61 & 12.69 & 4.20 & 8.17 & 1.15 & 1.96 & 11.02 & 3.86 & 6.72 & 2.51 & 2.12 & 12.11 & 4.00 & 7.25 \\
\hline
\end{tabular}


This simulation-optimization model can be applied to other drainage basins with similar characterizes of ADW in South Korea hence it may aid to estimate the permissible waste load to be released into a drain. Moreover, to attain suitable reuse water for irrigation and to manage the total pollution load in the drain.

Figure 7 shows how the objective function decreases at each iteration with Jaya algorithm. This provides evidence in favor of optimality of the Jaya Algorithm as the graph converges to the minimum with the given accuracy.

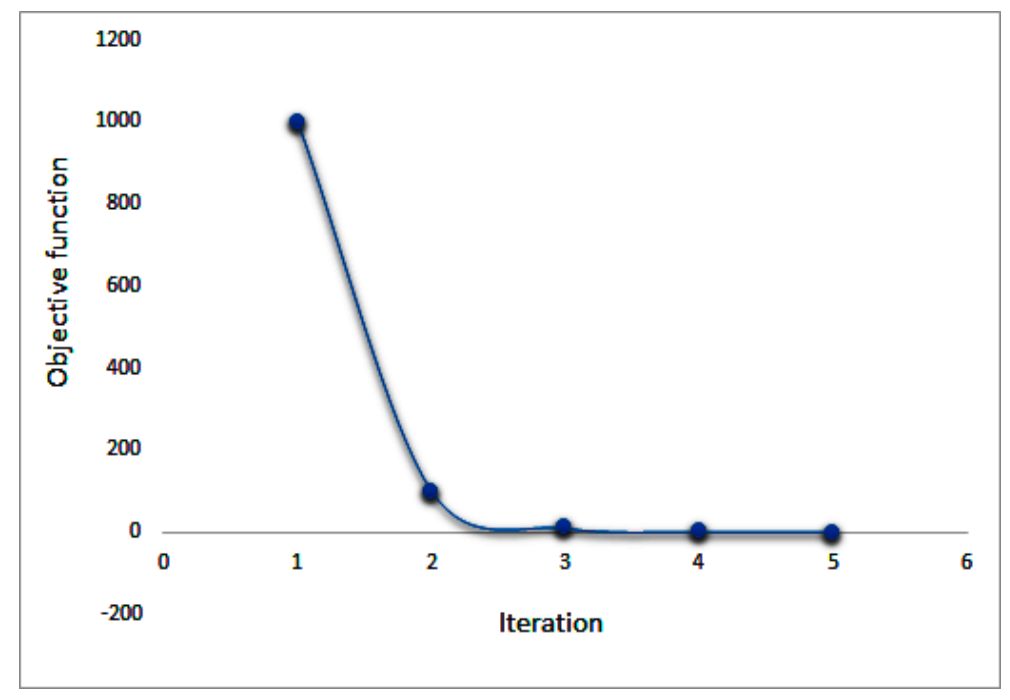

Figure 7. Objective function vs iteration for Jaya Algorithm.

\section{Conclusions}

A simulation optimization methodology was developed and applied to Osan Stream, South Korea, for the reuse of ADW in irrigation. This study simulates the water quality of the Osan stream drain using surface water quality model, QUAL2Kw and an optimization algorithm, Jaya algorithm. Jaya algorithm was used to determine the optimal reuse of ADW at five proposed reuse sites.

Results show that ADW from the Osan stream drainage basin can be used directly for irrigation at the five reuse locations with only a few violations of Korean standards and FAO guidelines. Thus, mixing wastewater with freshwater increases its suitability for irrigation and makes it suitable for irrigation. The QUAL2Kw model was calibrated and applied using data obtained during the period 2014-2016. Water quality results show accepted levels of BOD, DO, TN and TSS. Uncertainty and sensitivity analyses were applied to QUAL2Kw to verify the input variable. Uncertainty analysis predictions are reliable for both summer and winter while the sensitivity analysis showed that the contribution to variance parameter makes up about $95 \%$ of the sensitivity analysis showed the variance contributions of the parameters accounted for up to $95 \%$ of the variance. The optimization results showed that the reuse quantities can reach $49.1 \%$ and $54.5 \%$ ADW available in the summer and winter drain. These quantities represent $80 \%$ and $54.6 \%$ of the demand for fresh irrigation water in the drainage basin for summer and winter. This approach can be extended to irrigated systems to other drain irrigation systems with similar characteristics. Finally, the simulation-optimization model may improve the decision making on agricultural drainage water for irrigation for mixed watersheds.

Author Contributions: A.A. developed the methodology and conducted the work under the supervision and review of S.-I.L.

Funding: This subject was supported by Korea Ministry of Environment (MOE) as “Water Management Research Program (18AWMP-B079625-05)" and by Basic Science Research Program through the National Research Foundation (NRF) funded by the ministry grant (NRF-2018R1D1A1A09083120).

Conflicts of Interest: The authors declare no conflict of interest. 


\section{References}

1. FAO. Coping with Water Scarcity—Challenge of the Twenty-First Century; FAO: Rome, Italy, 2007.

2. World Health Organization (WHO). Guidelines for the Safe Use of Wastewater, Excreta and Greywater, Volume 2: Wastewater Use in Agriculture; World Health Organization: Geneva, Switzerland, 2006.

3. Hamilton, A.J.; Stagnitti, F.; Xiong, X.; Kreidil, S.L.; Benke, K.K.; Maher, P. Wastewater irrigation: The state of play. Vadose Zone J. 2007, 6, 823-840. [CrossRef]

4. Ministry of Construction and Transportation. National Water Resource Plan; MOCT: Seoul, Korea, 2012. (In Korean)

5. Ministry of Environment. Wastewater Reuse Guide Book; MOE: Seoul, Korea, 2009. (In Korean)

6. Ministry of Land, Transportation and Maritime Affairs (MLTM). Water Vision 2020 (2006 National Water Resources Plan Update); MLTM: Seoul, Korea, 2006. (In Korean)

7. Blumenthal, U.J.; Peasy, A.; Ruiz-Palacios, G.; Mara, D.D. Guidelines for Wastewater Reuse in Agriculture and Aquaculture: Recommended Revisions Based on New Research Evidence; WELL Study, Task No. 68 (Part 1); WELL Resource Centre: London, UK, 2000.

8. Jeong, H.; Kim, H.; Jang, T.; Park, S. Assessing the effects of indirect wastewater reuse on paddy irrigation in the Osan River watershed in Korea using the SWAT model. Agric. Water Manag. 2016, 163, 393-402. [CrossRef]

9. Kalburgi, P.; Shivayogimath, C.; Purandara, B. Application of QUAL2K for water quality modeling of river Ghataprabha (India). J. Environ. Sci. Eng. 2010, 4, 37.

10. Vasudevan, M.; Nambi, I.; Suresh, K. Application of QUAL2K for assessing waste loading project in river Yamuna. Int. J. Adv. Eng. Technol. 2011, 2, 336-344.

11. Gikas, G. Water quality of drainage canals and assessment of nutrient loads using QUAL2Kw. Environ. Process. 2014, 1, 369-385. [CrossRef]

12. Fliefle, A.; Saavedraina, O.; Yoshimura, C.; Elzeir, M.; Tawfik, A. Optimization of integrated water quality management for agricultural efficiency and environmental conservation. Environ. Sci. Pollut. Res. 2014, 21, 8095-8111. [CrossRef] [PubMed]

13. Allam, A.; Tawfik, A.; Yoshimura, C.; Fleifle, A. Simulation-based optimization framework for reuse of agricultural drainage water in irrigation. J. Environ. Manag. 2016, 172, 82-96. [CrossRef] [PubMed]

14. Rashed, A.; El-Sayed, E. Simulating agricultural drainage water reuse using QUAL2K Model: Case study of the Ismailia canal catchment area. J. Irrig. Drain. Eng. 2014, 140, 501-511. [CrossRef]

15. Song, J.H.; Jeong, H.S.; Park, J.H.; Song, I.H.; Kang, M.S.; Park, S.W. Analysis of water quality and soil environment in paddy fields partially irrigated with untreated wastewater. J. Korean Soc. Agric. Eng. 2014, 56, 19-29.

16. American Public Health Association (APHA); American Water Works Association (AWWA); Water Environment Federation (WEF). Standard Methods for the Examination of Water and Wastewater, 20th ed.; United Book Press, Inc.: Baltimore, MD, USA, 1998.

17. Ministry of Environment. Environmental Review 2011; MOE: Seoul, Korea, 2011. (In Korean)

18. Brown, L.; Barnwell, T. The Enhanced Stream Water Quality Models QUAL2E and QUAL2E-UNCAS: Documentation and User Manual; Environmental Research Laboratory, Office of Research and Development, US Environmental Protection Agency: Athens, GA, USA, 1987.

19. Pelletier, G. YASAI.xla: A Modified Version of an Open-Source Add-In for Excel to Provide Additional Functions for Monte Carlo Simulation; Department of Ecology: Washington, DC, USA, 2009. Available online: http: / / www.ecy.wa.gov / programs/eap/models.html (accessed on 1 January 2018).

20. Models and Tools for Water Quality Improvement. Available online: https://ecology.wa.gov/ResearchData/Data-resources/Models-spreadsheets/Modeling-the-environment/Models-tools-for-TMDLs (accessed on 1 January 2017).

21. Pelletier, G.; Chapra, S. A Modeling Framework for Simulating River and Stream Water Quality. QUAL2Kw Theory Documentation; 2005. Available online: http:/ /www.ecy.wa.gov/programs/eap/models/ (accessed on 1 January 2018).

22. Chapra, S.; Pelletier, G.; Tao, H. QUAL2K: A Modeling Framework for Simulating River and Stream Water Quality, Version 2.11: Documentation and User's Manual; Civil and Environmental Engineering Department, Tufts University: Medford, MA, USA, 2008. 
23. Hye, K.J.; Seok, J.H.; Seong, K.M.; Hong, S.I.; Park, S.W. Simulation of 10-day Irrigation Water Quality Using SWAT-QUALKO2 Linkage Model. J. Korean Soc. Agric. Eng. 2012, 54, 53-63. [CrossRef]

24. Caviness, K.; Garey, A.; Patrick, N. Modeling the Big Black River: A comparison of water quality models. J. Am. Water Resour. Assoc. 2006, 42, 617-627. [CrossRef]

25. Paliwal, R.; Sharma, P.; Kansal, A. Water quality modelling of the river Yamuna (India) using QUAL2E-UNCAS. J. Environ. Manag. 2007, 2, 1-14. [CrossRef] [PubMed]

26. Kim, H.D.; Lee, G.Y.; Lee, Y.G. Application of wastewater reuse system for agriculture: Status and prospects. Mag. Korea Water Resour. Assoc. 2009, 42, 36-43. (In Korean)

27. Sharma, D.; Kansal, A.; Pelletier, G. Water quality modeling for urban reach of Yamuna River, India (1999-2009), using QUAL2Kw. Appl. Water Sci. 2015. [CrossRef]

28. Eckstein, J.; Riedmueller, S.; Reed, S. YASAI: Yet Another Simulation Add-in for Excel. Version 2.0 User Guide. 2000. Available online: http:/ / www.yasai.rutgers.edu/yasai-guide-20html (accessed on 1 January 2018).

29. Eckstein, J.; Riedmueller, S. YASAI: Yet Another Add in for Teaching Elementary Monte Carlo Simulation in Excel; Rutcor Research Report (RRR) 27-2001, APRIL; Rutgers University: Piscataway, NJ, USA, 2001.

30. Eckstein, J.; Riedmueller, S. YASAI: Yet another add in for teaching elementary Monte Carlo simulation in Excel. Inf. Trans. Educ. 2002, 2, 12-26. [CrossRef]

31. Rao, R. Jaya: A simple and new optimization algorithm for solving constrained and unconstrained optimization problems. Int. J. Ind. Eng. Comput. 2016, 7, 19-34.

32. Jang, T.; Lee, S.B.; Sung, C.H.; Lee, H.P.; Park, S.W. Safe application of reclaimed water reuse for agriculture in Kora. Paddy Water Environ. 2010, 8, 227-233. [CrossRef]

33. Enforcement Decree of the Framework Act on Environmental Policy; Article 2, No. 23967; FAO: Rome, Italy, 2012. (In Korean)

(C) 2018 by the authors. Licensee MDPI, Basel, Switzerland. This article is an open access article distributed under the terms and conditions of the Creative Commons Attribution (CC BY) license (http://creativecommons.org/licenses/by/4.0/). 